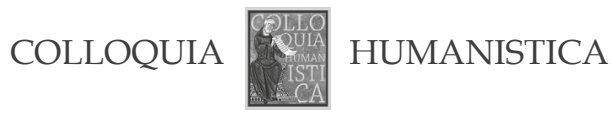

From the Editors

\title{
The Third Edition of the Inka Brodzka-Wald Award
}

n 16 June 2015, the Academy for the Development of Philanthropy in Poland and the Adam Mickiewicz Literary Society announced the winners of the third edition of the Inka Brodzka-Wald Award for doctoral dissertations in the humanities. The competition was open for theses which concerned present issues and were defended in 2014. We are pleased to inform that among recipients of honorary mentions was Doctor Katarzyna Taczyńska for Obraz Goli otok w serbskim dyskursie literackim $i$ historycznym końca XX $i$ poczatku XXI wieku [The Image of Goli Otok in Serbian Literary and Historical Discourse of the Late-Twentieth to Early-Twenty-First Century], written under the supervision of Professor Jolanta Sujecka (The Faculty of "Artes Liberales," University of Warsaw). Altogether three awards and three honorary mentions were granted by the Awarding Chapter, which comprised distinguished human scientists: Professor Maryla Hopfinger-Amsterdamska, Professor Grażyna Borkowska, Professor Jan Kordys, Professor Marek Zaleski, Adjunct Professor Doctor Tomasz Żukowski of the Institute of Literary Research, Polish Academy of Sciences, and Doctor Wincenty Cesluk-Grajewski of the Institute of Polish Literature, University of Warsaw.

The first prize was awarded to Natalia Gruenpeter for Czas, ciało, pamięć. Fotografia w paradygmacie kina [Time, Body, Memory. Photography with the Paradigm of Cinema], supervised by Professor Andrzej Gwóźdź;

This is an Open Access article distributed under the terms of the Creative Commons Attribution 3.0 PL License (creativecommons.org/licenses/by/3.0/pl/), which permits redistribution, commercial and non-commercial, provided that the article is properly cited. (C) The Author(s), 2016

Publisher: Institute of Slavic Studies, Polish Academy of Sciences

Editor-in-chief: Jolanta Sujecka

Conception and academic editing of this issue: Jolanta Sujecka 
the second prize was shared between Tatiana Wojtas for Problemy w polsko-rosyjskim komunikowaniu się na przykładzie mieszanych związków małżenskich $i$ nieformalnych [Problems in Polish-Russian Intercultural Communication - Evidence from Cross Marriages and Informal Partnerships], supervised by Professor Lech Mróz, and Olga Kaczmarek for Inaczej niż pisać. Tekst i kontrtekstowość jako problem metodologiczny $i$ etyczny: Lévinas $i$ antropologia postmodernistyczna [Otherwise Than Writing. Text and Counter-Textuality as a Problem of Methodology and Ethics: Lévinas and Postmodern Anthropology], supervised by Professor Grzegorz Godlewski. The two other honorary mentions were Anna Mach for Poetyka postpamięci i etyka świadka-spadkobiercy Zagłady w polskiej literaturze najnowszej [Poetics of Postmemory and the Ethics of the Holocaust Secondary Witnessing in Polish Contemporary Literature], supervised by Professor Mieczysław Dąbrowski, and Marcin Dzikowski for Projekty „nowego człowieka” w wybranych powieściach końca XIX i początku $X X$ wieku $w$ kręgu kulturalizmu. Próba rozpoznania [The Project of the "New Man" in Selected Culturalist Novels of the Late-Nineteenth to Early-Twentieth Century], supervised by Professor Maria Jolanta Olszewska.

Doctor Katarzyna Taczyńska is a Polish and Balkan studies scholar, member of the Laboratory for Research on Collective Memory in Post-Communist Europe at the Nicholas Copernicus University in Torun (SONATA 2 National Centre for Science grant no. 2011/03/D/HS2/06170, headed by Doctor Rigels Halili). She is also a co-editor of the Poznać Batkany [Getting to Know the Balkans] book series. 